\title{
Effective method for the production of anti-fog (dew- -resistant) coatings based on bifunctional polysiloxanes
}

\author{
Izabela Dąbek ${ }^{1)}$, Marta Kaczmarek ${ }^{2)}$, Joanna Karasiewicz ${ }^{2)}$, Jacek Guliński ${ }^{1), 2)}$, Hieronim \\ Maciejewski ${ }^{1), 2), *)}$
}

DOI: dx.doi.org/10.14314/polimery.2020.11.8

\begin{abstract}
Anti-fog (dew-resistant) coatings were produced employing as active components bifunctional polysiloxanes containing polyether (hydrophilic and polar) groups and trialkoxysilyl groups (permitting durable adhesion to glass surface). These bifunctional polysiloxanes were obtained as a result of consequent hydrosilylation of allyl polyethers and vinyltrialkoxysilane with the use of poly(dimethyl-co-hydromethyl)siloxane. The effect of structure of the polysiloxane used (length of siloxane chain, length of polyether chain, content of functional groups) and its concentration of the coating performance were analyzed. The designed preparation permits easy production of a durable anti-fog and dew-resistant coating from widely accessible raw materials and with no need of special pretreatment of glass surface.
\end{abstract}

Keywords: organofunctional polysiloxanes, anti-fog coatings, dew-resistant coatings.

\section{Efektywna metoda wytwarzania powłok przeciwmgielnych (przeciwroszeniowych) na bazie dwufunkcyjnych polisiloksanów}

\begin{abstract}
Streszczenie: Powłoki przeciwmgielne (przeciwroszeniowe) wytworzono z zastosowaniem - jako składników aktywnych - dwufunkcyjnych polisiloksanów zawierających grupy polieterowe (hydrofilowe i polarne) oraz grup trialkoksysililowych (umożliwiających trwałe przyłączenie do powierzchni szkła). Zbadano wpływ struktury zastosowanego polisiloksanu (długość łańcucha siloksanowego, długość łańcucha polieterowego, zawartość grup funkcyjnych) i jego stężenia na efektywność tworzenia powłok. Opracowany preparat umożliwia łatwą produkcję trwałej powłoki przeciwmgielnej i przeciwroszeniowej z powszechnie dostępnych surowców i bez potrzeby specjalnego przygotowania powierzchni szklanej.
\end{abstract}

Słowa kluczowe: organofunkcyjne polisiloksany, powłoki przeciwmgielne, powłoki przeciwroszeniowe.

Transparent materials, e.g. glass and some polymers, are widely used in everyday life. In normal conditions they are covered with dew because of the unavoidable condensation of steam on solid surfaces. The deposition of dew is a consequence of the presence of water molecules dispersed in the air. The air saturated with steam composed of molecules large enough to diffuse light shows limited light transmittance. The same effect is caused by deposition of dew on transparent materials as a result of which they lose transparency and cannot function correctly. Steam undergoes condensation on solid surfaces at temperatures below the dew point that can be reached by increase in local humidity or decrease in the temperature of the solid surface [1]. As a consequence the optical properties of the transparent materials (light transmittance) are seriously hampered. The problems with light transmittance related to dew formation are our everyday occurrence, e.g. dew deposition on a mirror in the bathroom, on glasses, on swim goggles, binoculars, glass lenses or camera lenses [2,3]. Steaming is a source of many problems in different areas in which materials of top optical properties are needed. For instance condensation deteriorates the accuracy of certain analytical instruments and microscopes [4]. Diffused field of vision is of utmost importance in airplane flying and motor vehicle driving for safety reasons $[5,6]$, in certain surgical procedures like, e.g. endoscopic surgery $[7,8]$. The problems also appear when sunlight energy is to be maximally used, e.g. in hothouses where dew can significantly reduce light transmittance leading to decreased yield [9]. Dew deposition on photovoltaic panels also reduces their effectiveness [10].

\footnotetext{
1) Poznan Science and Technology Park Adam Mickiewicz University Foundation, Rubież 46, 61-612 Poznań, Poland.

2) Adam Mickiewicz University in Poznan, Faculty of Chemistry, Uniwersytetu Poznańskiego 8, 61-614 Poznań, Poland.

*) Author for correspondence: maciejm@amu.edu.pl
} 


\section{METHODS OF PROTECTING TRANSPARENT MATERIALS AGAINST STEAMING}

There are two categories of strategies aimed at protection against steaming [11]. The first one is based on changes in the environment parameters, including relative air humidity, temperature and air stream. The most often proposed solutions include heating of materials, e.g. by applying external voltage and increased air flow [12-14]. The second type strategies are based on the adjustment of the interaction between the water drop and the glass surface achieved by changed composition or roughness of the material surface to get proper conditions of wetting. Most often the material surface is covered with special coatings or modified to change the features of the surface. The application of the latter procedures seems more attractive as it is easier, cost-effective and ensures longer effects.

Covering the surface of transparent materials with thin films of specific properties is one of the most effective methods for obtaining anti-fog (dew-resistant) surfaces. The coatings are made of natural or synthetic water-soluble polymers (WSPs) containing hydrophilic functional groups, e.g. hydroxyl $(\mathrm{OH})$ [15-18], carboxyl or ester groups $(\mathrm{COOH} / \mathrm{COOR}),[16,17,19]$, amine $\left(\mathrm{NH}_{2}\right)[16,20,21]$, sulfonic $\left(\mathrm{SO}_{3} \mathrm{H}\right)$ or dihydrophosphate groups $\left(\mathrm{PO}_{4} \mathrm{H}_{2}\right)$ [22] The main reason for using such polymers is that these groups are capable of interacting with water molecules, usually through hydrogen bonds and dipolar interactions, which leads to formation of a continuous or quasi-continuous layer of water. WSPs have been chosen for production of anti-fog (dew-resistant) coatings thanks to their elasticity, transparency, low cost and possibility of modification of their functionality through chemical reactions. Unfortunately, because of their natural hydrophilic character these coatings show propensity to dissolution in water [23]. In order to increase the coatings stability and increase the time of their functioning, often cross-linking agents are applied, leading to formation of the cross-linked polymer network [23]. Cross-linking may be stimulated by UV irradiation or heating. Although such coatings are cohesive and well cross-linked, they are characterized by poor adhesion to the surface, depending only on the physical interaction between the two materials [23].

As mentioned above, the anti-fog (dew-resistant) coatings are obtained from natural and synthetic water-soluble polymers. Natural polymers such as cellulose and related hydrophilic polysaccharides show a number of attractive features as nontoxicity, environmental neutrality and biological compatibility [24, 25]. Moreover, to achieve desired wetting properties, e.g. increase hydrophilic or hydrophobic character, these polymers can be modified through introduction of appropriate functional groups. The water-soluble polymers used for production of anti-fog (dew-resistant) coatings include pullulan [15], chitosan [16, 19, 20], cellulose derivatives such as quaternary cellulose [17], carboxymethylcellulose [16, 17, 19] and its nanocrystals [21], alginate and hyaluronic acid [16]. The synthetic water-soluble poly- mers used for the same purpose are, e.g. poly(vinyl alcohol) (PVA) [23, 26-28] and poly(acrylic acid) (PAA) [27, 29]. The strength of PVA coatings can be enhanced applying bifunctional cross-linking agents such as dialdehydes or carboxylic acids [30]. An interesting polymer also used for the same purpose is poly(ethylene glycol) (PEG) [poly(ethylene oxide), PEO] [31, 32]. Its hydrophilic molecules endow the coatings with the ability to absorb water and PEG is itself a cross-linking agent so it improves chemical and mechanical stability of coatings with no compromise to their anti-fog (dew-resistant) properties. Promising materials protecting against steaming were also found to be epoxy resins, e.g. those based on isosorbide [33].

Besides the organic polymers also inorganic materials can be used, divided into two groups. The first one includes hydrophilic materials such as $\mathrm{SiO}_{2}$, graphene oxide [34, 35] or $\mathrm{In}_{2} \mathrm{O}_{3}-\mathrm{SnO}_{2}$, presented in [36] in different forms: as solid particles, empty or mesoporous nanoparticles, nanofibers and nanorods. The second group comprises photoactive materials such as $\mathrm{TiO}_{2}[37,38]$ or $\mathrm{ZnO}$ [39], which become superhydrophilic when exposed to UV irradiation or sunlight (after certain chemical or physical modifications). Recently, the $\mathrm{SiO}_{2}$ coatings have been very popular because of no need of their activation with UV irradiation. Moreover, they were characterized by greater light transmittance than the titanium dioxide coatings as the light reflectance of silica is lower than that of $\mathrm{TiO}_{2}$. Strongly hydrophilic properties of silica are related to the presence of silanol groups on its surface $[40,41]$. The silica layers are most often by the dip-coating technique $[42,43]$ and should be fixed by drying or calcination even at $500^{\circ} \mathrm{C}$ [43]. Thus, although these materials permit getting durable superhydrophilic foils, the foil deposition requiring thermal processing make it difficult to use them on polymer materials. In order to obtain dew-resistant properties, a number of surface modifications, both chemical and physical have been used to increase the surface roughness. The physical methods are etching, plasma or gamma radiation treatment [44]. The chemical methods include covering with multilayer coatings $[45,46]$ or generation of rough structures similar to the shape of raspberry fruit $[47,48]$. All the above methods require the use of drastic conditions (temperature, $\mathrm{pH}$ ), solvents that can have degrading effect on the substrate or are complicated and thus cost and work consuming or do not ensure a stable effect of surface modification. In this paper we present a simple, cheap and effective method of modification of transparent materials ensuring stable protection against steaming.

\section{EXPERIMENTAL PART}

\section{Materials}

Poly(dimethyl-co-hydromethyl)siloxanes and vinyltrimethoxysilane were purchased from $\mathrm{ABCR} \mathrm{GmbH}$, allyl polyethers - from ICSO Chemical Production, while Karstedt catalyst and all solvents were purchased from Aldrich. Glass plates were purchased from Thermo Scientific. 


\section{Synthesis of bifunctional polysiloxanes}

Polysiloxanes containing polyether and trialkoxysilyl groups were synthesized by the hydrosilylation reaction of poly(dimethyl-co-hydromethyl)siloxane with allyl polyether and subsequently vinyltriethoxysilane $[49,50]$. Polysiloxanes with different siloxane chain lengths and different $\mathrm{Si}-\mathrm{H}$ contents were employed in the synthesis, which produced several derivatives. The process was carried out in the presence of Karstedt complex $\left\{\mathrm{Pt}_{2}\left[\left(\mathrm{CH}_{2}=\mathrm{CHSiMe}\right)_{2} \mathrm{O}_{3}\right\}\right.$ as catalyst. The procedure for the synthesis of an exemplary bifunctional polysiloxane is shown below: $\left[\left(\mathrm{CH}_{3}\right)_{3} \mathrm{Si}\right]$ $\left[\mathrm{OSi}\left(\mathrm{CH}_{3}\right)_{2}\right]_{50}\left[\mathrm{OSi}\left(\mathrm{CH}_{3}\right)\left(\mathrm{CH}_{2} \mathrm{CH}_{2} \mathrm{Si}\left(\mathrm{OC}_{2} \mathrm{H}_{5}\right)_{3}\right]_{10}\left[\mathrm{OSi}\left(\mathrm{CH}_{3}\right)\right.\right.$ $\left.\left(\mathrm{CH}_{2}\right)_{3}\left(\mathrm{OC}_{2} \mathrm{H}_{4}\right)_{7} \mathrm{OH}\right]_{15}\left[\mathrm{OSi}\left(\mathrm{CH}_{3}\right)_{3}\right] 42 \mathrm{~g}$ of poly(dimethylco-hydromethyl)siloxane $\left[\left(\mathrm{CH}_{3}\right)_{3} \mathrm{Si}\right]\left[\mathrm{OSi}\left(\mathrm{CH}_{3}\right)_{2}\right]_{50}\left[\mathrm{OSi}\left(\mathrm{CH}_{3}\right)\right.$ $\mathrm{H}]_{25}\left[\mathrm{OSi}\left(\mathrm{CH}_{3}\right)_{3}\right]$ and $15 \mathrm{~g}$ of vinyltriethoxysilane $\left(\mathrm{CH}_{2}=\mathrm{CHSi}\left(\mathrm{OC}_{2} \mathrm{H}_{5}\right)_{3}\right.$ were placed in a three-neck round bottom flask equipped with a thermometer, reflux condenser and magnetic bar. A catalyst $\left(5 \cdot 10^{-5} \mathrm{~mol}\right.$ Pt per mol Si-H) was then added at room temperature. After the introduction of the catalyst, the solution was heated to $100^{\circ} \mathrm{C}$. When complete conversion of vinyltriethoxysilane occurred (as monitored by FT-IR analysis), $43 \mathrm{~g}$ of allyl polyether $\mathrm{CH}_{2}=\mathrm{CHCH}_{2}\left(\mathrm{OC}_{2} \mathrm{H}_{4}\right)_{7} \mathrm{OH}$ was added. The solution was maintained for $1 \mathrm{~h}$ at the same temperature as before. Then, the reaction mixture was cooled, to yield the viscous, yellow liquid as a product.

NMR analyses of the product confirmed its structure:

${ }^{1} \mathrm{H}$ NMR $\left(\mathrm{C}_{6} \mathrm{D}_{6}, 298 \mathrm{~K}, 300 \mathrm{MHz}\right)$ ppm: $0.12[18 \mathrm{H}$, $\left.\mathrm{Si}\left(\mathrm{CH}_{3}\right)_{3}\right] ; 0.19\left(375 \mathrm{H}, \mathrm{SiCH}_{3}\right) ; 0.42\left(70 \mathrm{H}, \mathrm{SiCH}_{2}\right) ; 1.22$ $\left(90 \mathrm{H}, \mathrm{OCH}_{2} \mathrm{CH}_{3}\right) ; 1.47\left(30 \mathrm{H}, \mathrm{SiCH}_{2} \mathrm{CH}_{2}\right) ; 3.34(30 \mathrm{H}$, $\left.\mathrm{SiCH}_{2} \mathrm{CH}_{2} \mathrm{CH}_{2}\right) ; 3.58\left(420 \mathrm{H},-\mathrm{OCH}_{2} \mathrm{CH}_{2}^{-}\right) ; 3.82(60 \mathrm{H}$, $\mathrm{OCH}_{2} \mathrm{CH}_{3}$ ).

${ }^{13} \mathrm{C}$ NMR $\left(\mathrm{C}_{6} \mathrm{D}_{6}, 298 \mathrm{~K}, 75.5 \mathrm{MHz}\right)$ ppm: $-0.59\left[\mathrm{Si}\left(\mathrm{CH}_{3}\right)_{3}\right]$; $1.03\left(-\mathrm{OSiCH}_{3} \mathrm{O}-\right) ; 13.33\left(-\mathrm{SiCH}_{2}\right) ; 18.46\left(\mathrm{OCH}_{2} \mathrm{CH}_{3}\right) ; 23.02$ $\left(-\mathrm{SiCH}_{2} \mathrm{CH}_{2}\right) ; 58.47\left(\mathrm{OCH}_{2} \mathrm{CH}_{3}\right) ; 61.61\left(-\mathrm{SiCH}_{2} \mathrm{CH}_{2} \mathrm{CH}_{2}\right)$; $70.52\left(-\mathrm{OCH}_{2} \mathrm{CH}_{2}-\right)$.

${ }^{29} \mathrm{Si} \mathrm{NMR}\left(\mathrm{C}_{6} \mathrm{D}_{6}, 298 \mathrm{~K}, 59.6 \mathrm{MHz}\right)$ ppm: $7.21\left[\mathrm{Si}\left(\mathrm{CH}_{3}\right)_{3}\right]$; $-21.42\left[\mathrm{Si}\left(\mathrm{CH}_{3}\right)_{2}\right] ;-21.97\left[\mathrm{Si}\left(\mathrm{CH}_{3}\right) \mathrm{CH}_{2}\right] ;-46.07\left[\mathrm{Si}\left(\mathrm{OCH}_{2} \mathrm{CH}_{3}\right]\right.$.

\section{Synthesis of anti-fog and dew-resistant preparations}

Bifunctional polysiloxane of a defined structure was dissolved in a mixture of isopropyl alcohol, water and poly(ethylene glycol), ensuring the ratio of $\left[{ }^{\mathrm{PrOH}}\right]:\left[\mathrm{H}_{2} \mathrm{O}\right]:[\mathrm{PEG}]$ equal to $2: 1: 0.08$, in order to obtain solutions containing the bifunctional polysiloxane in the concentration of 1, 2, 5 and $10 \%$. The solutions were then acidified with acetic acid to get $\mathrm{pH}$ of 3.5-4 and stirred at room temperature for $1 \mathrm{~h}$, after this time the preparation was ready to use.

\section{Deposition of the preparation onto glass plates}

Glass plates were washed with a mixture of water and detergent, then washed a few times with demineralized water and acetone and dried in a vacuum desiccator. With the help of an atomizer the preparations were deposited onto glass surfaces and left to dry. After drying the glass surface coated with the preparation film was polished with a cotton cloth and the samples were subjected to the tests.

\section{Methods of testing}

\section{Determination of hydrophilic properties}

The water contact angles were measured using an automatic video contact-angle testing apparatus Krüss model DSA 100 Expert. A $0.010 \mathrm{~cm}^{3}$ volume of water was applied onto the treated plates and the contact angle was determined from the video camera images of the drop in the course of its formation. Each value is an average from five drops.

\section{FT-IR analysis}

FT-IR spectra of the modified plates were taken on a Bruker spectrometer, model Tensor 27, with a Specac Golden Gate single reflection diamond ATR accessory.

\section{Tests}

Following the procedure described in [51], the samples made of glass plates coated with the obtained preparations were subjected to application tests. All the tests were performed for the coated sample and the reference uncoated sample.

Test 1

A beaker containing boiling water was covered with the coated sample and the reference sample and their steaming was compared. If the coated sample remained transparent the coating was evaluated as effective (very good) and showing full dew-resistant effect. If the coated sample was partly steamed, but to lesser degree than the reference sample, the coating was evaluated as good. If the coated sample was steamed to a degree similar to that of the reference sample, the coating was classified as unsatisfactory.

Test 2

The samples were placed in a refrigerator at $4^{\circ} \mathrm{C}$ for 1 $h$, then the degree of steaming was evaluated according to the same criteria as above.

Test 3

The samples were placed in a freezer at $-20^{\circ} \mathrm{C}$ for $1 \mathrm{~h}$ and then the degree of steaming was evaluated, if the coated sample was steamed the time in which it became transparent was measured.

\section{RESULTS AND DISCUSSION}

In our study we used derivatives of polysiloxanes (silicones). Typical silicones contain methyl groups, that endow hydrophobic properties to the compounds and are linked to silicon atom. Silicones show high thermal stability, low surface energy and are chemically inert, which 
makes them attractive for applications in many areas of industry and in everyday life [52]. Of increasing significance are modified polysiloxanes, combining the characteristic features of a siloxane chain and the properties and reactivity of a certain functional group [53]. There are different methods of polysiloxanes functionalization, although hydrosilylation is one of the easiest ways for introduction of a certain functional group to a polysiloxane chain [54].

The study was performed using bifunctional polysiloxanes containing polyether and trialkoxysilyl groups. These derivatives were obtained in the reaction of consecutive hydrosilylation, with the use of allyl polyethers and vinyltrimethoxysilane with poly(dimethyl-co-hydromethyl)siloxane [49, 50], according to Scheme A:

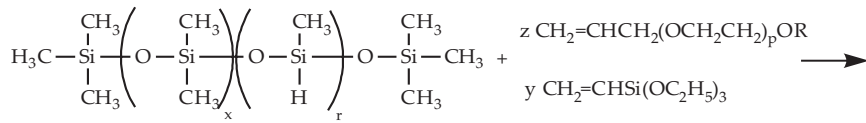

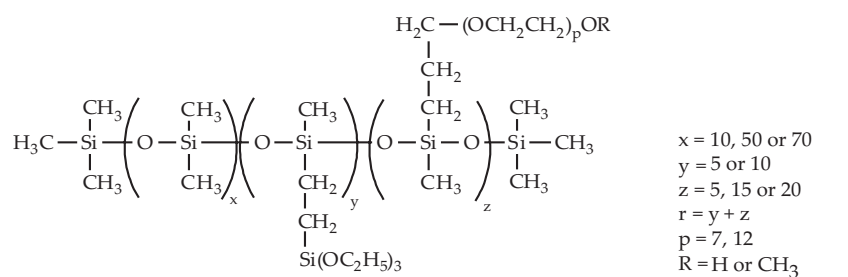

Scheme. A. Synthesis of bifunctional polysiloxanes based on consecutive hydrosilylation

As polyether groups show hydrophilic and polar character, in combination with the polysiloxane chain they give a hybrid material of amphiphilic properties. The trialkoxysilyl group as a result of hydrolysis and condensation with hydroxyl groups on the surface of glass permits a stable connection of the modified polysiloxane with the glass. In order to establish the effect of certain types of functionalized polysiloxanes on the properties of the final product, we used polysiloxanes of different chain length and different content of $\mathrm{Si}-\mathrm{H}$ groups and allyl polyethers of different content of ethoxy groups terminated with $-\mathrm{OH}$ or $-\mathrm{OCH}_{3}$ groups. All synthesized compounds were used for making a preparation that was deposited on glass surfaces. Bifunctional polysiloxanes were dissolved in a mixture of isopropyl alcohol, water and poly(ethylene glycol). Water is necessary for hydrolysis of alkoxyl groups in polysiloxane, while isopropyl alcohol is the solvent that makes the system homogenic. The addition of poly(ethylene glycol) delays the evaporation of the preparation deposited on the glass surface and improves its adhesion. To ensure effective hydrolysis and condensation, $\mathrm{pH}$ had to be maintained at a level of 3.5-4, which was achieved by addition of acetic acid. A few samples of the preparation, differing in the amounts 1, 2, 5 and $10 \mathrm{wt} \%$ of the active component (functionalized polysiloxane) were obtained. The preparations were deposited on clean glass surfaces by sputtering with the use of an atomizer or by rubbing the glass surface with a cloth wetted with a given preparation afterwards left to dry. The coatings obtained were subjected to FT-IR spectroscopic study and to wetting angle measurements.

Results of FT-IR analyses confirmed the presence of functionalized polysiloxane on the glass surface. Exemplary FT-IR spectra of two coatings made of preparations differing only in the terminal group of polyether $-\mathrm{OH}$ or $-\mathrm{OCH}_{3}$ are presented in Figs. 1 and 2.

The main difference is the presence of a signal at $3472 \mathrm{~cm}^{-1}$ (Fig. 1) assigned to the stretching vibrations of $-\mathrm{OH}$ bond. The spectra of both samples show signals at $2959 \mathrm{~cm}^{-1}$ and $2867 \mathrm{~cm}^{-1}$ assigned to the stretching vibrations of $\mathrm{C}-\mathrm{H}$, at $1454 \mathrm{~cm}^{-1}, 1411 \mathrm{~cm}^{-1}$ and $1350 \mathrm{~cm}^{-1}$ assigned to the deformation vibrations of $\mathrm{C}-\mathrm{H}$, at $1259 \mathrm{~cm}^{-1}$ coming from Si- $\mathrm{CH}_{3}$ group, at $1088 \mathrm{~cm}^{-1} \mathrm{com}-$ ing from the vibrations of $\mathrm{Si}-\mathrm{O}-\mathrm{Si}$, at $1013 \mathrm{~cm}^{-1}$ assigned to the $\mathrm{C}-\mathrm{O}-\mathrm{C}$ bond and at $796 \mathrm{~cm}^{-1}$ originating from the vibrations of $\mathrm{Si}-\mathrm{CH}_{3}$ group.

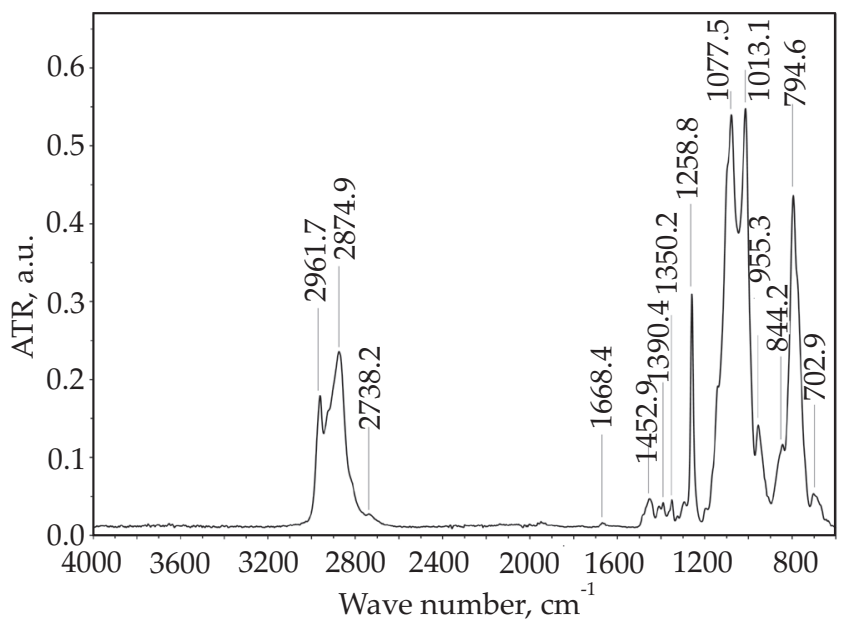

Fig. 2. FT-IR spectrum of the coating made of polysiloxane con- taining a polyether group with a terminal $-\mathrm{OCH}_{3}$ group
Fig. 1. FT-IR spectrum of the coating made of polysiloxane containing a polyether group with a terminal - $\mathrm{OH}$ group

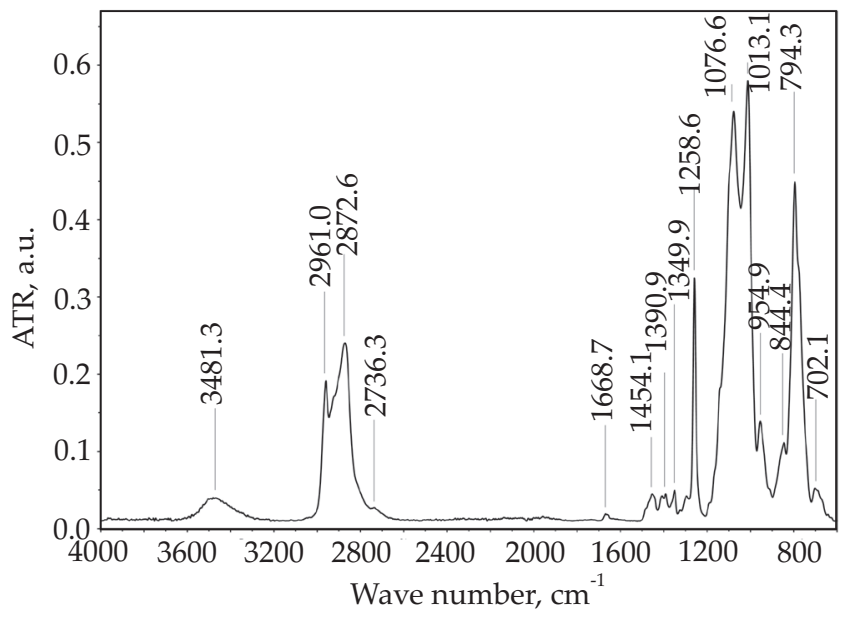


$\mathrm{T}$ a b 1 e 1. Contact angles measured for glass surfaces coated with preparations containing bifunctional polysiloxane $\left[\left(\mathrm{CH}_{3}\right)_{3} \mathrm{Si}\right]$ $\left[\mathrm{OSi}\left(\mathrm{CH}_{3}\right)_{2}\right]_{\mathrm{x}}\left[\mathrm{OSi}\left(\mathrm{CH}_{3}\right)\left(\mathrm{CH}_{2} \mathrm{CH}_{2} \mathrm{Si}\left(\mathrm{OC}_{2} \mathrm{H}_{5}\right)_{3}\right]_{\mathrm{y}}\left[\mathrm{OSi}\left(\mathrm{CH}_{3}\right)\left\{\left(\mathrm{CH}_{2}\right)_{3}\left(\mathrm{OC}_{2} \mathrm{H}_{4}\right)_{\mathrm{p}} \mathrm{OR}\right]_{\mathrm{z}}\left[\mathrm{OSi}\left(\mathrm{CH}_{3}\right)_{3}\right]\right.\right.$

\begin{tabular}{|c|c|c|c|c|c|c|c|}
\hline \multirow{2}{*}{ Sample } & \multicolumn{5}{|c|}{ Bifunctional polysiloxane } & \multirow{2}{*}{$\begin{array}{c}\text { Concentration } \\
\text { wt } \%\end{array}$} & \multirow{2}{*}{$\begin{array}{c}\text { WCA } \\
{\left[{ }^{\circ}\right]}\end{array}$} \\
\hline & $\mathrm{x}$ & $\mathrm{y}$ & $\mathrm{z}$ & $\mathrm{p}$ & $\mathrm{R}$ & & \\
\hline 1 & 50 & 5 & 20 & 7 & $\mathrm{H}$ & 1 & 45 \\
\hline 2 & 50 & 5 & 20 & 7 & $\mathrm{H}$ & 2 & 25 \\
\hline 3 & 50 & 5 & 20 & 7 & $\mathrm{H}$ & 5 & $<10^{*}$ \\
\hline 4 & 50 & 5 & 20 & 7 & $\mathrm{H}$ & 10 & $<10^{*}$ \\
\hline 5 & 50 & 5 & 20 & 7 & $\mathrm{CH} 3$ & 5 & 25 \\
\hline 6 & 50 & 10 & 15 & 7 & $\mathrm{H}$ & 5 & 25 \\
\hline 7 & 50 & 5 & 20 & 12 & $\mathrm{H}$ & 5 & $<10^{*}$ \\
\hline 8 & 50 & 5 & 20 & 12 & $\mathrm{CH} 3$ & 5 & 25 \\
\hline 9 & 10 & 5 & 5 & 7 & $\mathrm{CH} 3$ & 5 & 45 \\
\hline 10 & 70 & 10 & 20 & 7 & $\mathrm{CH} 3$ & 5 & 30 \\
\hline $11^{* *}$ & 50 & 5 & 20 & 12 & $\mathrm{H}$ & 5 & $<10^{*}$ \\
\hline $12^{* *}$ & 50 & 5 & 20 & 7 & $\mathrm{H}$ & 5 & $<10^{*}$ \\
\hline
\end{tabular}

* - water contact angle (WAC) unmeasurable by the instrument used; ${ }^{* *}$ - water contact angle measured for the coated plate 5 times washed with water and dried by rubbing with a cloth.

$\mathrm{T}$ a b 1 e 2. Results of experiments testing anti-fog properties of glass plates coated with $\left[\left(\mathrm{CH}_{3}\right)_{3} \mathrm{Si}\right]\left[\mathrm{OSi}_{(}\left(\mathrm{CH}_{3}\right)_{2}\right]_{x}\left[\mathrm{OSi}_{(}\left(\mathrm{CH}_{3}\right)\right.$ $\left(\mathrm{CH}_{2} \mathrm{CH}_{2} \mathrm{Si}\left(\mathrm{OC}_{2} \mathrm{H}_{5}\right)_{3}\right]_{\mathrm{y}}\left[\mathrm{OSi}\left(\mathrm{CH}_{3}\right)\left\{\left(\mathrm{CH}_{2}\right)_{3}\left(\mathrm{OC}_{2} \mathrm{H}_{4}\right)_{\mathrm{p}} \mathrm{OR}\right]_{\mathrm{z}}\left[\mathrm{OSi}\left(\mathrm{CH}_{3}\right)_{3}\right]\right.$

\begin{tabular}{|c|c|c|c|c|c|c|c|c|c|}
\hline \multirow{2}{*}{ Sample } & \multicolumn{5}{|c|}{ Bifunctional polysiloxane } & \multirow{2}{*}{$\begin{array}{c}\text { Concentration } \\
\text { wt } \%\end{array}$} & \multirow{2}{*}{ Test 1} & \multirow{2}{*}{ Test 2} & \multirow{2}{*}{ Test 3} \\
\hline & $x$ & $\mathrm{y}$ & $\mathrm{z}$ & $\mathrm{p}$ & $\mathrm{R}$ & & & & \\
\hline 1 & 50 & 5 & 20 & 7 & $\mathrm{H}$ & 1 & + & + & + \\
\hline 2 & 50 & 5 & 20 & 7 & $\mathrm{H}$ & 2 & ++ & + & + \\
\hline 3 & 50 & 5 & 20 & 7 & $\mathrm{H}$ & 5 & +++ & +++ & $+++(5)$ \\
\hline 4 & 50 & 5 & 20 & 7 & $\mathrm{H}$ & 10 & +++ & +++ & $+++(5)$ \\
\hline 5 & 50 & 5 & 20 & 7 & $\mathrm{CH} 3$ & 5 & ++ & ++ & $++(30)$ \\
\hline 6 & 50 & 10 & 15 & 7 & $\mathrm{H}$ & 5 & ++ & ++ & $++(25)$ \\
\hline 7 & 50 & 5 & 20 & 12 & $\mathrm{H}$ & 5 & +++ & ++ & $++(20)$ \\
\hline 8 & 50 & 5 & 20 & 12 & $\mathrm{CH} 3$ & 5 & +++ & ++ & $++(25)$ \\
\hline 9 & 10 & 5 & 5 & 7 & $\mathrm{CH} 3$ & 5 & ++ & + & + \\
\hline 10 & 70 & 10 & 20 & 7 & $\mathrm{CH} 3$ & 5 & +++ & ++ & $++(35)$ \\
\hline $11^{* *}$ & 50 & 5 & 20 & 12 & $\mathrm{H}$ & 5 & +++ & +++ & $++(25)$ \\
\hline $12^{* *}$ & 50 & 5 & 20 & 7 & $\mathrm{H}$ & 5 & +++ & ++ & $++(15)$ \\
\hline
\end{tabular}

+++-very good; ++-good; +- unsatisfactory; in parentheses: time of evaporation in seconds for the samples for which this time was shorter than $60 \mathrm{~s} ;{ }^{* *}$ - glass sample coated with the preparation proposed and 5 times washed with water and dried by rubbing with a cloth.

The properties of the coated surface were characterized by the measurements of the contact angle (wetting angle) by the sessile drop technique, the results are given in Table 1.

On the basis of the data from Table 1 it can be concluded that the glass surfaces covered with all types of coatings were hydrophilic, although the surfaces covered with a few coatings were so easily wettable that the contact angle measurement was impossible (the drop immediately spread over). Contact angle measurements permitted determination of the optimum concentration of the active substance ( $5 \mathrm{wt} \%$ ) for which the wettability was maximum. These results also indicated that the coating surface wettability depended on type of the terminal groups in polyether group. For the derivatives with the terminal $-\mathrm{OCH}_{3}$ groups the contact angles were higher (contact angle measurement was possible) than for those with the terminal -OH groups (samples 3 and 5, and samples 7 and 8). The contact angle value was not affected by the length of the polyether chain, but it definitely was affected by the length of the polysiloxane chain. For the sample with a short polysiloxane chain (sample 9) the contact angle was much higher than for the other samples. Besides the length of the polysiloxane chain, also the number of functional (polyether) groups per the unit length of the chain has impact on the contact angle. For instance, sample 10 contains a longer polysiloxane chain, but a lower number of polyether group (per the unit length of the chain) than sample 5 , and the contact angle obtained for the former is higher than for the latter. The durability of the coatings is illustrated by the con- 


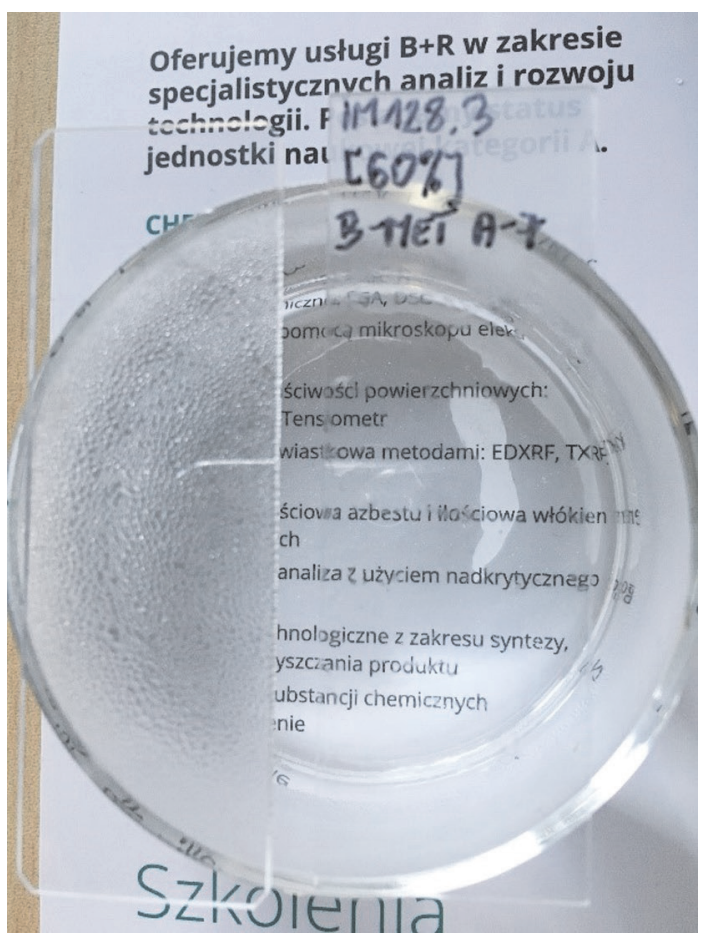

Fig. 3. A photograph illustrating the dew-resistant effect of the coating containing $5 \mathrm{wt} \%$ of bifunctional polysiloxane, sample 3

tact angles determined for samples 11 and 12. These two samples were prepared in the same way as samples 7 and 3 , but for the former two the contact angle was measured after five times repeated washing and drying, not immediately after deposition of coating like for samples 3 and 7. For all four samples $(3,7,11,12)$ the same results were obtained. The contact angles were below $10^{\circ}$, which means that the coating shows hydrophilic properties. At the next stage the anti-fog (dew-resistant) properties of the coated surfaces were tested. Following the procedure described in [54] the dew resistance was tested by three methods. All tests were based on comparison between the pure glass plate and the glass plate coated with a given preparation. In the first test the glass plate and coated glass plate were exposed to steam. If the coated plate remained transparent the coat was evaluated as effective (very good) and showing dew resistance. If the coated sample was partly steamed but less than the pure glass plate, the coating was evaluated as good. If the coated sample was steamed to a degree similar to the pure glass, the coating was evaluated as unsatisfactory. In the second method, the analogous set of samples were placed in a refrigerator and left there for 1 hour at $4^{\circ} \mathrm{C}$. After this time the samples were taken out of the fridge and the steaming was evaluated applying the scale similar to that used in method 1 . In the third method, the analogous set of samples were placed in the freezer and kept there for 1 hour at $-20^{\circ} \mathrm{C}$. After this time the plates were taken out and if the coated plate was steamed it was observed how much time is needed to make it transparent. Table 2 presents the results for all the samples for which contact angles were measured and presented in Table 1.

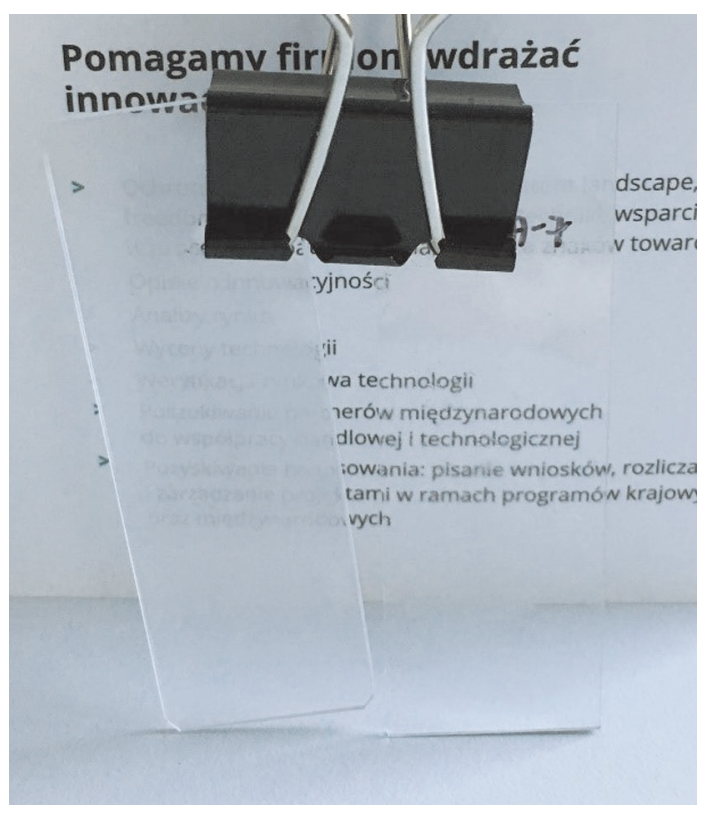

Fig. 4. The dew-resistant effect of the best coating containing $5 \mathrm{wt} \%$ of bifunctional polysiloxane (sample 3) contrasted with the reference sample in test 2

The tests results permitted selection of coatings showing anti-fog (dew-resistant) activity. Although the majority of the coated surfaces were hydrophilic or strongly hydrophilic, only some of them were found to show dew resistance. The results revealed the best performance of the sample coated with the preparation containing $5 \mathrm{wt} \%$ of bifunctional polysiloxane, samples $1-4$. The test observations confirmed the conclusions following from the contact angle measurements, i.e. that the coating with the too short siloxane chain (sample 9) and that with a long siloxane chain but with a too low number of hydrophilic groups (sample 10) showed much poorer performance. The best results were obtained for the coating containing polyether groups with terminal hydroxyl groups (samples $3,4,7,11,12$ ). Figure 3 is a photograph showing the dew-resistant effect achieved covering a glass plate with the coating containing $5 \mathrm{wt} \%$ of bifunctional polysiloxane, sample 3, contrasted with the steamed reference plate.

The most demanding test was that number 3 (freezer) as the samples taken out from the very low temperature show high propensity to steaming. All coated plated were steamed, although the samples with best coatings very quickly became transparent, which illustrated the effect of the coating (Fig. 4). The best results in test 3 were also obtained for sample 3 . The rubbing and washing tests, samples 11 and 12, confirmed the durability of the coatings, which maintained their properties after a few times washing and rubbing. The modification of glass surfaces with the bifunctional polysiloxane is realized through condensation of alkoxyl groups with the hydroxyl groups present on the glass, as schematically shown in Scheme B.

The presence of alkoxyl groups permits generation of stable bonding to glass. The properly adjusted $\mathrm{pH}$, at 


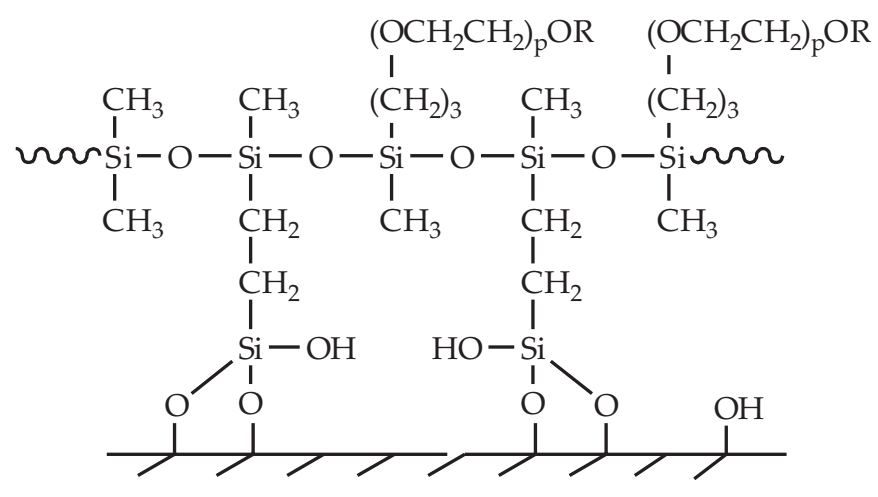

Scheme B. Modification of glass plate surface with bifunctional polysiloxane

a level of 3-4 facilitates hydrolysis of the alkoxyl groups and formation of the active silanol groups that undergo condensation with the hydroxyl groups on the glass surface. Thanks to the structure of the siloxane chain (every second substituent at the oxygen atom is missing) and its properties (it is flexible, capable of assuming certain orientation on the surface and has low surface energy) it is possible to achieve uniform coverage of glass plates. The coating modified with bifunctional polysiloxanes is characterized by strong adhesive properties determined by the proper arrangement of the functional groups attached to the siloxane chain, as shown in Scheme B. Effectiveness of the modification depends also on the correct ratio of the functional groups in polysiloxane. Excess of alkoxyl substituents may make the chain lose the flexibility and become too stiff. When the siloxane chain has fewer connections with glass substrate it is more flexible and the hydrophilic polyether groups can easier assume a desired orientation on the surface. The polar polyether groups are directed outward of the surface making a uniform transparent film that facilitates dispersion of water droplets. Moreover, the presence of oxygen atoms in their structure enables them to interact with the glass surface through hydrogen bonds thus stabilizing the coating. The applied polysiloxane shows excellent dew-resistant properties because of a low surface energy and is able to uniformly spread on the surface of the support and form a homogeneous coating. Steam deposited on the coating is quickly dispersed, which makes the film transparent and permits fast run-off of water droplets. The siloxane chain is hydrophobic and anti-adhesive, so in winter conditions or for surfaces in refrigerators of freezers the ice layer is weaker attached to the coating surface, which facilitates its removal.

\section{CONCLUSIONS}

Thanks to the use of bifunctional polysiloxanes for modification of transparent surfaces it was possible to obtain in a simple and cost-effective way durable coatings showing anti-fog and dew-resistant properties. The presence of polyether groups in a polysiloxane chain endows the coating with strongly hydrophilic character, while the presence of trialkoxysilyl groups permits stable connection with the support surface. Analysis of the effect of the polysiloxane structure on the coating properties has shown that the longer the siloxane chain and the greater the content of polyether groups, the better the anti-fog properties. It has been also established that better properties were obtained for the derivatives whose polyether groups were terminated with hydroxyl groups, instead of alkoxyl ones. The best anti-fog and dew-resistant properties were observed for the coating containing the polysiloxane of the following chemical formula: $\left[\left(\mathrm{CH}_{3}\right)_{3} \mathrm{Si}\right]$ $\left[\mathrm{OSi}\left(\mathrm{CH}_{3}\right)_{2}\right]_{50} \mathrm{OSi}\left(\mathrm{CH}_{3}\right)\left(\mathrm{CH}_{2} \mathrm{CH}_{2} \mathrm{Si}\left(\mathrm{OC}_{2} \mathrm{H}_{5}\right)_{3}\right]_{5}\left[\mathrm{OSi}\left(\mathrm{CH}_{3}\right)\right.$ $\left\{\left(\mathrm{CH}_{2}\right)_{3}\left(\mathrm{OC}_{2} \mathrm{H}_{4}\right)_{7} \mathrm{OH}\right]_{20}\left[\mathrm{OSi}\left(\mathrm{CH}_{3}\right)_{3}\right]$ (sample 3). The preparation based on this polysiloxane [55] permits a durable modification of the transparent material (glass) surface and effectively protects it from steaming. Owing to the hybrid character of bifunctional polysiloxane (polyether group is hydrophilic, while polysiloxane chain is hydrophobic and anti-adhesive) the steam is easily dispersed on the surface of the coating and water droplets easily run-off it. At low temperatures the coating properties permit easy removal of ice deposited on glass surface. The properties of the polysiloxane chain, i.e. its flexibility, ability to assume a certain orientation on the surface and low surface energy, ensure a uniform coverage. The use of bifunctional polysiloxanes containing polyether groups is one of the simplest, cheapest and at the same time most effective approaches to achieve a durable antifog and dew-resistant coating.

\section{ACKNOWLEDGMENTS}

The authors wish to acknowledge the financial assistance of the studies within the research project no. 2018/29/B/ ST8/00913, entitled "Synthesis and characterization of materials of defined surface properties", from the National Science Centre.

\section{REFERENCES}

[1] Agam N., Berliner P.R.: Journal of Arid Environments 2006, 65, 572. https://doi.org/10.1016/j.jaridenv.2005.09.004

[2] Crebolder J., Sloan R.: Applied Ergonomics 2004, 35, 371. https://doi.org/10.1016/j.apergo.2004.02.005

[3] Gallaway M., Aimino J., Scheiman M.: Optometry Journal of the American Optometric Association 1986, 57, 304.

[4] Oguri K., Iwataka N., Tonegawa A. et al.: Journal of Materials Research 2001, 16, 553. https://doi.org/10.1557/JMR.2001.0079

[5] San-Juan M., Martín Ó., Mirones B.J. et al.: Applied Thermal Engineering 2016, 104, 479. https://doi.org/10.1016/j.applthermaleng.2016.05.093

[6] Herbage G.D.: Aircraft Engineering and Aerospace Technology 1972, 44, 49. 
https://doi.org/10.1108/eb034941

[7] Nezhat C., Morozov V.: Journal of the Society of Laparoendoscopic Surgeons 2008, 12, 431.

[8] Lawrentschuk N., Fleshner N.E., Bolton D.M.: Journal of Endourology 2010, 24, 905. https://doi.org/10.1089/end.2009.0594

[9] Cai M.J.: Chinese Journal of Chemical Physics 2015, 28, 223. https://doi.org/10.1063/1674-0068/28/cjcp1412208

[10] Park J.T., Kim J.H., Lee D.: Nanoscale 2014, 6, 7362. https://doi.org/10.1039/C4NR00919C

[11] Duran I.R., Laroche G.: Progress in Materials Science 2019, 99, 106. https://doi.org/10.1016/j.pmatsci.2018.09.001

[12] Kim H.J., Kim Y., Jeong J.H. et al.: Journal of Materials Chemistry A 2015, 3, 16621. https://doi.org/10.1039/C5TA03348A

[13] Bae J.J., Lim S.C., Han G.H. et al.: Advanced Functional Materials 2012, 22, 4819. https://doi.org/10.1002/adfm.201201155

[14] Zhang G., Zou H., Qin F. et al.: Applied Thermal Engineering 2017, 115, 726. https://doi.org/10.1016/j.applthermaleng.2016.12.143

[15] Introzzi L., Fuentes-Alventosa J.M., Cozzolino C.A. et al.: ACS Applied Materials \& Interfaces 2012, 4, 3692. https://doi.org/10.1021/am300784n

[16] Nuraje N., Asmatulu R., Cohen R.E. et al.: Langmuir 2011, 27, 782. https://doi.org/10.1021/la103754a

[17] Shibraen M., Yagoub H., Zhang X. et al.: Applied Surface Science 2016, 370, 1. https://doi.org/10.1016/j.apsusc.2016.02.060

[18] Zhang X., He J.: Chemical Communications 2015, 51, 12661. https://doi.org/10.1039/C5CC04465K

[19] Lee H., Gilbert J.B., Angilè F.E. et al.: ACS Applied Materials \& Interfaces 2015, 7, 1004. https://doi.org/10.1021/am508157m

[20] Florea-Spiroiu M., Achimescu D., Stanculescu I. et al.: Polymer Bulletin 2013, 70, 3305. https://doi.org/10.1007/s00289-013-1023-z

[21] Li F., Biagioni P., Bollani M., Maccagnan A. et al.: Cellulose 2013, 20, 2491. https://doi.org/10.1007/s10570-013-0015-3

[22] Li L., Zhang G., Su Z.: Angewandte Chemie 2016, 55, 9093. https://doi:10.1002/anie.201604671

[23] Chevallier P., Turgeon S., Sarra-Bournet C. et al.: ACS Applied Materials \& Interfaces 2011, 3, 750. https://doi.org/10.1021/am1010964

[24] Swift G.: Polymer Degradation and Stability 1998, 59, 19. https://doi.org/10.1016/S0141-3910(97)00162-6

[25] Swift G.: Macromolecular Symposia 1998, 130, 379. https://doi.org/10.1002/masy.19981300132

[26] Zhang X., He J.: International Journal of Nanoscience 2015, 14, 1460015. https://doi.org/10.1142/S0219581X14600151
[27] Zhang X., He J.: Scientific Reports 2015, 5, 9227. https://doi.org/10.1038/srep09227

[28] Li Y., Fang X., Wang Y. et al.: Chemistry of Materials 2016, 28, 6975. https://doi.org/10.1021/acs.chemmater.6b02684

[29] Wang Y., Li T., Li S. et al.: Chemistry of Materials 2015, $27,8058$. https://doi.org/10.1021/acs.chemmater.5b03705

[30] Silva R., Muniz E.C., Rubira A.F.: Polymer 2008, 49, 4066. https://doi.org/10.1016/j.polymer.2008.07.051

[31] Molina E.F., Jesus C.R.N., Chiavacci L.A. et al.: Journal of Sol-Gel Science and Technology 2014, 70, 317. https://doi.org/10.1007/s10971-014-3300-1

[32] Nam E., Wong E.H.H., Tan S. et al.: Macromolecular Materials and Engineering 2017, 302, 1600199. https://doi.org/10.1002/mame.201600199

[33] Park S., Park S., Jang D.H. et al.: Materials Letters 2016, 180, 81. https://doi.org/10.1016/j.matlet.2016.05.114

[34] Bae J.J., Lim S.C., Han G.H. et al.: Advanced Functional Materials 2012, 22, 4819. https://doi.org/10.1002/adfm.201201155

[35] Tan L., Zeng M., Wu Q. et al.: Small 2015, 11, 1840. https://doi.org/10.1002/smll.201402427

[36] Park H.K., Yoon S.W., Chung W.W. et al.: Journal of Materials Chemistry A 2013, 1, 5860. https://doi.org/10.1039/C3TA10422B

[37] US Pat. 9028958 (2015).

[38] US Pat. 0336039 (2014).

[39] Kwak G., Jung S., Yong K.: Nanotechnology 2011, 22, 115705. https://doi.org/10.1088/0957-4484/22/11/115705

[40] McMillan P.F., Remmele R.L.: American Mineralogist 1986, 71, 772.

[41] Zhuravlev L.T.: Reaction Kinetics and Catalysis Letters 1993, 50, 15. https://doi.org/10.1007/BF02062184

[42] Innocenzi P.: Journal of Non-Crystalline Solids 2003, $316,309$. https://doi.org/10.1016/S0022-3093(02)01637-X

[43] Lu X., Wang Z., Yang X. et al.: Surface and Coatings Technology 2011, 206, 1490. https://doi.org/10.1016/j.surfcoat.2011.09.031

[44] Roach P., Eglin D., Rohde K. et al.: Journal of Materials Science Materials in Medicine 2007, 18, 1263. https://doi.org/10.1007/s10856-006-0064-3

[45] US Pat. 0113133 (2008).

[46] Liu X., Du X., He J.: ChemPhysChem 2008, 9, 305. https://doi.org/10.1002/cphc.200700712

[47] Du X., Liu X., Chen H. et al.: The Journal of Physical Chemistry C 2009, 113, 9063. https://doi.org/10.1021/jp9016344

[48] Li X., He J.: ACS Applied Materials \& Interfaces 2012, 4, 2204. https://doi.org/10.1021/am3002082

[49] PL Pat. 193689 (2007). 
[50] PL Pat. 211521 (2012).

[51] US Pat 3342740 (1967).

[52] Jones R.G., Ando W., Chojnowski J.: "SiliconContaining Polymers", Kluwer Academic Publishers, Dordrecht 2000.

[53] Brook M.A.: "Silicon in Organic, Organometallic and Polymer Chemistry", John Wiley \& Sons, New York 2000.
[54] Maciejewski H., Szubert K., Marciniec B.: Polimery 2009, 54, 626.

http://dx.doi.org/10.14314/polimery.2009.706

[55] PL Pat. Appl. 427499 (2018).

Received 25 V 2020.

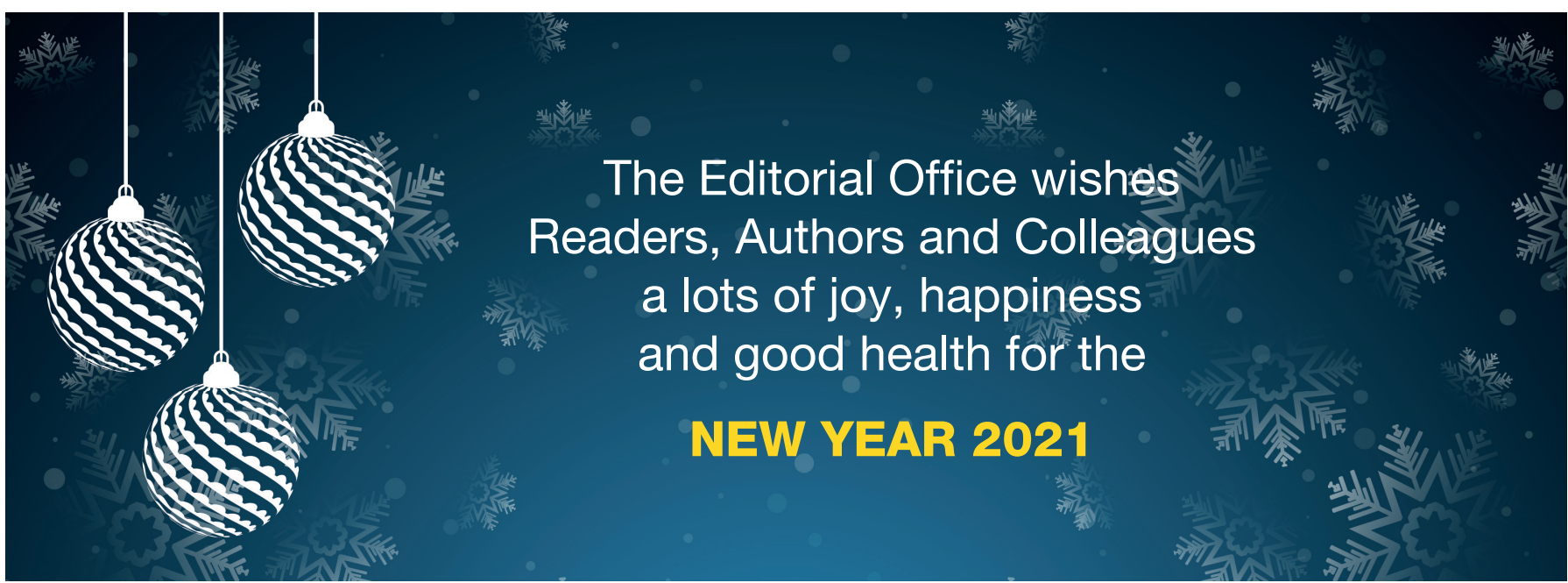

